\title{
COMPARISON OF MOTIVATION FOR PARENTING IN HEALTHY AND DEPRESSED PATIENTS
}

\author{
Numanović ŠS. Almedina, ${ }^{1}$ Mladenović J. Željko, ${ }^{1}$ Hazirović B. Rešad, ${ }^{2}$ Jovičić M. Milena ${ }^{3}$ \\ ${ }^{1}$ International university Novi Pazar, Serbia \\ ${ }^{2}$ General hospital Novi Pazar, Serbia \\ ${ }^{3}$ Clinical center Kragujevac, Clinic for psychiatry, Kragujevac, Serbia
}

Primljen/Received 02. 09. 2018. god.

Abstract: Objective: The aim of present study was to examine whether there is a difference in parenting motives between patients diagnosed with depression and control groups (non-depressed). Material and Method: The survey included 66 patients who were treated at the Psychiatric Hospital in Novi Pazar (average age $=44.64, \mathrm{SD}=10.00$ ) and 65 subjects who were not diagnosed with depression (average age $=42$, $\mathrm{SD}=13.05)$. Participants volunteered to participate in the research and received no compensation for their participation. Respondents were given a Parent Motivation Scale. Results: Results showed that participants in our study are motivated for parenthood mostly by instrumental motivation, altruistic and fatalistic motivations are equally present, and narcissistic motivation is the lowest. Instrumental, fatalistic and altruistic motives for parenting are significantly lower in group consisted of depressed patients. There was no difference in narcissistic motivation between two groups. Conclusion: This finding can be seen in the light of the general condition and the characteristic of people suffering from depression. In them, namely, all aspects of motivation are reduced and it is not surprising that this is so with the motives for parenting.

Key words: depression, altruistic, fatalistic, narcissistic, instrumental motivation.

\section{INTRODUCTION}

\section{Depression}

Depression is the psychological condition in which mood is changed and this impairs the person's basic state of mind, perception, body condition, behaviour and social functioning (1). Depressive mood is characterized by turning the patient to himself, despondency, collapse of the vital dynamism, sleeplessness,
Prihvaćen/Accepted 01. 11. 2018. god.

appetite loss, pessimism, slow process of thought, hopelessness and helplessness $(2,3,4)$.

It is considered that depression is caused by genetic, environmental, psychological, and biochemical factors. Depression usually starts between the ages of 15 and 30, and is much more common in women. Approximately $7 \%$ to $12 \%$ of men and $20 \%$ to $25 \%$ of women suffer from depression during lifetime. Women can also get postpartum depression after the birth of a baby. Some people get seasonal affective disorder in the winter. Depression is one part of bipolar disorder (5). Several scientific studies determined statistic correlations between depression and the use of certain agricultural pesticides (6).

Depression is much more than a passing feeling of sadness and fatigue; patients with depression often present complex and overlapping emotional and physical symptoms, including pain complaints. In everyday clinical practice we often see patients with depression co-morbid with physical diseases where depression increases health care costs, leading to lower cooperation in the treatment and clinical outcome is worse. Depression is sometimes not recognized or misdiagnosed, and delaying of the treatment increases the suffering of the patient and his environment. Undiagnosed and untreated severe depression leads to attempted suicide or in some cases murder of family members. Contemporary data show that suicide risk is most common in depressed patients and shows an increasing trend. Number of suicide is higher in men then in women. In recent years we have had intensive research of biology of depression and suicidality. The key is a holistic approach and determination of the mental status of a person, and diagnosis is made on the basis of agreed diagnostic criteria contained in CD- 10 classification (7).

Depressive disorder is a significant problem in the field of mental health worldwide. According to the 
World Health Organization, depression is fourth biggest global health problem, by the year 2020. it will become the second global health issue, also it is the largest cause of disability among adults (8).

There are two main groups of theoretical approaches to depression. One group considers depression as a consequence of psychological factors, in Behaviourist theory of learning, Psychodynamic theory- Freud (1917), Cognitive approach- Beck's (1967) theory, Humanist approach- Maslow (1962).

In the second group there are theories that accentuate biological and physiological factors. Current neurobiological theories with the most valid empirical foundation are based on studies investigating psychosocial stress and stress hormones, proinflammatory cytokines, neurotransmitters such as serotonin, norepinephrine, dopamine, glutamate and gamma-aminobutyric acid (GABA), neurocircuitry, neurotrophic factors, and circadian rhythms. According to one model, depression can be considered as a psychoneuroimmune disease in which peripheral immune activation is stimulated by secretion of mediators of the inflammation which is responsible for numerous behavioural, neuroendocrine and neurochemical changes which are related to psychiatric condition (9). Collected data indicate the equal importance of serotonin, norepinephrine and dopamine in the occurrence of depressive mood, and in that relation were synthesized new effective antidepressants (11).

\section{Motivation for parenting}

Hoffman and Hoffman (1973) amongst first examined the value which children have for parents. Nine groups of such values have been identified, from economic and practical values (e.g., showing the status of an adult or economic gain) to psychological (e.g., parenting). It seems that with the advancement of society the economic value of the child decreases (for example, the child seen as a work force or as support in old age), and its psychological value increases (mutual love, attachment, sense of fulfilment, etc.) (12).

Research has shown that fertility motivation is influenced by many factors, from the biological, personal meanings for potential parents (psychological needs, attitudes and values), socioeconomic factors (material condition, education, employment, housing issues), to the quality of the partner relationship of potential parents to the historical and social circumstances and internal norms related to the fertility behaviour that the individual adopted during socialization in his family and the wider social environment $(13,14,15$, 16). Also, a parenting motive for those who are already parents can be changed depending on sex, number of children and their order of birth $(17,18)$.
One of the first responses to the question what parents expect from children and what kind of parent's needs children should fulfil was given by Rabin (19), who grouped the motivation for parenting into four categories. Altruistic motivation involves love for children, a desire to care for them, to give them love and protection, and so on. Fatalistic motivation refers to the belief that reproduction and extension of the species is the meaning of life, human destiny or God's will; it's something that is predetermined and inevitable. When a child is seen as a means by which some specific parent goals can be achieved (e.g. material profits, old age support, etc.), this is an instrumental motivation. Finally, the narcissistic motivation for parenting relates to the expectation that a child will increase the value of parents, that it will be evidence of his sexual capacity and masculinity, or femininity.

It is obvious that for the same persons, motivation for parenting can be conditioned by multiple and different reasons. We can differentiate the reasons by their strength, their focus on themselves and other features. But, as one could expect, the greatest correlation was between instrumental and narcissistic motivation, because in both types of motivation, the child serves to achieve a parental goal, whether it is continuation of a family line, transfer of a family name, insurance in old age or even proving of their own value (20).

The unselfish altruistic motivation, expressed in the desire to have a child for love, the joy that it provides and the desire to care for the child, separates this type of motivation from other categories of motivation for parenting. It is therefore not surprising that its connection with narcissistic motivation was the weakest and, in general, its connection with other categories of motivation was lower than the interconnectedness of the other three categories of motivation for parenting (20). Of course, these motives are not mutually exclusive, they can also be found in a variety of combinations.

Parenthood that begins with one type of motive (for example, fatalist) can later be enriched with other types (for example, altruistic motifs). Belsky has dealt with parental behaviour issues and has come up with three main groups of factors that influence parental behaviour, such as: the individual characteristics of parents, the characteristics of the child and contextual factors (21). Individual characteristics of parents that influence parental behaviour are age, sex, behaviour of their parents towards them, knowledge and beliefs about child development and satisfaction with marriage (12). On the other hand, there are also the characteristics of the child that will direct parental behaviour, and this includes child's gender, age, temperament and abilities. Then, contextual factors have a major impact on the interaction and relationship of the child and par- 
ents, because parental behaviour does not take place in social isolation, but in interaction, socialization and communication with the child. That is why we include factors such as: parent's social networks, workplace, marital relations etc. (21). All the factors that we listed could cause stress, but also support. For example, stress at work that can affect and change behaviour towards a child, as much as the perception of marital relationships affects parental behaviour, so if a woman feels the support from her husband, she is more likely to deal more easily with her children (21).

\section{OBJECTIVE}

The aim of present study was to examine whether there is a difference in parenting motives between patients diagnosed with depression and control groups (non-depressed).

\section{MATERIAL AND METHOD}

The survey included 66 patients who were treated at the Psychiatric Hospital in Novi Pazar (average age = $44.64, \mathrm{SD}=10.00$ ) and 65 subjects who were not diagnosed with depression (average age $=42, \mathrm{SD}=13.05$ ). Participants volunteered to participate in the research and received no compensation for their participation.

Respondents were given a Parent Motivation Scale (22). The scale consists of 52 claims where respondents mark the number (0 "I do not agree" to the 4 "I fully agree") to match their agreement with given claim. Scale examines four types of motivation for parenting: altruistic, fatalistic, narcissistic and instrumental. They also received a short questionnaire on socio-demographic characteristics (gender, age, marital status and education level).

Retrospective study has been used. For statistical analysis we used the methods of descriptive statistics, $t$ test and Spearman's correlation coefficient. Data processing was performed using SPSS 20.

\section{RESULTS}

We first checked the ratio of presence of four types of parenting motives among respondents. That is, we wanted to see which motive is the most represented, and whether some of the motives are present to the same extent within same respondent.

As we can see from Table 1 instrumental motivation is the strongest, altruistic motivation and fatalistic motivation are nearly equal, and altruistic motivation is the lowest.

A repeated measures ANOVA with a Greenhouse-Geisser correction because of the violated assumption of sphericity, determined that there is statistically significant difference in the presence of each of the four parenting motives in the individual respondent $(\mathrm{F}$ $(1.456,189.266)=947.736, \mathrm{p}<0.01)$.

Post hoc pairwise comparisons using the Bonferroni correction (Table 2.) revealed that there is statistically significant difference between pairs of participant's scores on altruistic, narcissistic, instrumental motivation $(p<0.01)$, and as it could be expected from Table 1 there is no significant difference between scores on altruistic and fatalistic motivation.

One way ANOVA was performed in order to see whether depressed patients differ significantly from

Table 1. Mean and standard deviation of the participants scores on types of motivation for parenting

\begin{tabular}{|l|c|c|c|}
\hline & Mean & $\begin{array}{c}\text { Std. } \\
\text { Deviation }\end{array}$ & $\mathrm{N}$ \\
\hline Altruistic motivation & 37.90 & 8.144 & 131 \\
\hline Fatalistic motivation & 37.70 & 8.466 & 131 \\
\hline Narcissistic motivation & 12.95 & 4.154 & 131 \\
\hline Instrumental motivation & 70.73 & 19.609 & 131 \\
\hline
\end{tabular}

Table 2. Pairwise comparison of the participants scores on types of motivation for parenting

\begin{tabular}{|l|l|c|c|c|}
\hline \multicolumn{1}{|c|}{ (I) factor 1 } & \multicolumn{1}{|c|}{$(\mathrm{J})$ factor 1 } & Mean Difference (I-J) & Std. Error & Sig. \\
\hline Altruistic & Fatalistic m. & .198 & .509 & 1.000 \\
Motivation & Narcissistic $\mathrm{m}$. & 24.947 & .756 & 0.001 \\
& Instrumental m. & -32.832 & 1.271 & 0.001 \\
\hline Fatalistic & Altruistic m. & -.198 & .509 & 1.000 \\
Motivation & Narcissistic m. & 24.748 & .733 & 0.001 \\
& Instrumental m. & -33.031 & 1.195 & 0.001 \\
\hline Narcissistic & Altruistic m. & -24.947 & .756 & 0.001 \\
motivation & Fatalistic m. & -24.748 & .733 & 0.001 \\
& Instrumental m. & -57.779 & 1.644 & 0.001 \\
\hline Instrumental & Altruistic m. & 32.832 & 1.271 & 0.001 \\
motivation & Fatalistic m. & 33.031 & 1.195 & 0.001 \\
& Narcissistic $\mathrm{m}$. & 57.779 & 1.644 & 0.001 \\
\hline
\end{tabular}


Table 3. Mean value and standard deviation of the four parenting motives in compared groups

\begin{tabular}{|l|l|c|c|c|}
\hline \multicolumn{2}{|l|}{} & N & Mean & Std. Deviation \\
\hline \multirow{3}{*}{ Altruistic motivation } & Depressed patients & 66 & 32.41 & 7.547 \\
& Control group & 65 & 43.48 & 3.767 \\
& Total & 131 & 37.90 & 8.144 \\
\hline \multirow{3}{*}{ Fatalistic Motivation } & Depressed patients & 66 & 31.67 & 7.478 \\
& Control group & 65 & 43.83 & 3.617 \\
& Total & 131 & 37.70 & 8.466 \\
\hline \multirow{3}{*}{ Narcissistic motivation } & Depressed patients & 66 & 12.86 & 4.121 \\
& Control group & 65 & 13.05 & 4.218 \\
& Total & 131 & 12.95 & 4.154 \\
\hline \multirow{3}{*}{ Instrumental Motivation } & Depressed patients & 66 & 55.24 & 15.940 \\
& Control group & 65 & 86.46 & 4.925 \\
& Total & 131 & 70.73 & 19.609 \\
\hline
\end{tabular}

Table 4. Results of the ANOVA used for comparing the groups in strength of their parenting motives

\begin{tabular}{|l|l|c|c|c|c|c|}
\hline & & $\begin{array}{c}\text { Sum of } \\
\text { Squares }\end{array}$ & Df & $\begin{array}{c}\text { Mean } \\
\text { Square }\end{array}$ & F & Sig. \\
\hline \multirow{3}{*}{ Altruistic motivation } & Between Groups & 4011.540 & 1 & 4011.540 & 112.249 & 0.001 \\
& Within Groups & 4610.170 & 129 & 35.738 & & \\
& Total & 8621.710 & 130 & & & \\
\hline \multirow{3}{*}{ Fatalistic motivation } & Between Groups & 4845.584 & 1 & 4845.584 & 139.783 & 0.001 \\
& Within Groups & 4471.805 & 129 & 34.665 & & \\
& Total & 9317.389 & 130 & & & \\
\hline \multirow{3}{*}{ Narcissistic motivation } & Between Groups & 1.091 & 1 & 1.091 & .063 & 0.803 \\
& Within Groups & 2242.634 & 129 & 17.385 & & \\
\hline \multirow{3}{*}{ Instrumental motivation } & Total & 2243.725 & 130 & & & \\
& Between Groups & 31917.374 & 1 & 31917.374 & 227.877 & 0.001 \\
& Within Groups & 18068.275 & 129 & 140.064 & & \\
\hline
\end{tabular}

control group of non-depressed participants in parental motivation. Table 3 shows mean and standard deviation of the scores on four motives for parenting, as it could be seen scores of the control group are higher than in group of depressed patients for all motives except for narcissistic. Results of the ANOVA from Table 4 show that differences seen in Table 3 are statistically significant $(p<$ 0.01), except for narcissistic motivation.

\section{DISCUSSION}

Results showed that participants in our study are motivated for parenthood mostly by instrumental motivation, altruistic and fatalistic motivations are equally present, and narcissistic motivation is the lowest. It should be noted that the strength of the instrumental motive is almost twice as high as altruistic and fatalistic motivation, and as six times as narcissistic (Table 1). This is a new and interesting finding, somewhat unexpected, since we have shown the results of the research Tucak-Junaković and Ahmeti in which a strong correlation was found between instrumental and narcissistic motivation (20). Someone could have thought that this was a consequence of the fact that half of the sample was consisted of depressed patients in whom narcissism is reduced, but as it could be seen in Table 3 , control group also has low narcissistic motivation for parenting not statistically different from depressed participants (Table 4).

Another important finding shows that instrumental, fatalistic and altruistic motives for parenting are significantly lower in group consisted of depressed patients. The individual experiences himself both as the seller and as the commodity to be sold on the market, his self-esteem depending on conditions beyond his control. If he is žsuccessful' he is valuable; if he is not "successful" he is worthless. The degree of insecurity which results from this orientation can hardly be overestimated. If one feels that one's own value is not constituted primarily by the human values one possesses, but by one's success on a competitive market with ever-changing conditions, one's self-esteem, is bound to be shaky 
and is in constant need of confirmation by others. Hence one is driven to strive relentlessly for success, and any setback is a severe threat to one's self-esteem; helplessness, insecurity, and inferiority feelings are the result. If the vicissitudes of the market are the judges of one's value, the sense of dignity and pride is destroyed (22).

\section{CONCLUSION}

This finding can be seen in the light of the general condition and the characteristic of people suffering from depression. In them, namely, all aspects of moti- vation are reduced it is not surprising that this is so with the motives for parenting.

\section{DECLARATION OF INTEREST}

The autors declare that there are no conflicts of interests.

\section{Licensing}

This work is licensed under a Creative Commons Attribution 4.0 International (CC BY 4.0) License.

\title{
Sažetak
}

\section{KOMPARACIJA MOTIVACIJE ZA RODITELJSTVO KOD ZDRAVIH I DEPRESIVNIH PACIJENATA}

\author{
Numanović Š. Almedina, ${ }^{1}$ Mladenović J. Željko, ${ }^{1}$ Hazirović B. Rešad, ${ }^{2}$ Jovičić M. Milena ${ }^{3}$ \\ ${ }^{1}$ International university Novi Pazar, Serbia \\ ${ }^{2}$ General hospital Novi Pazar, Serbia \\ ${ }^{3}$ Clinical center Kragujevac, Clinic for psychiatry, Kragujevac, Serbia
}

Cilj: Svrha ove studije bila je da ispita da li postoji razlika u roditeljskim motivima između roditelja kojima je dijagnostikovana depresija i kontrolne grupe (bez depresije). Materijal i Metode: Istraživanje je obuhvatilo 66 pacijenata koji su lečeni u Službi za psihijatriju bolnice $\mathrm{u}$ Novom Pazaru (prosečne godine $=44.64, \mathrm{SD}=$ 10.00) i 65 osoba kojima nije dijagnostikovana depresija (prosečne godine $=42, \mathrm{SD}=13.05$ ). Učesnici su svojevoljno učestvovali u istraživanju i za to nisu dobili nikakvu novčanu naknadu. Ispitanicima je data Skala za Roditeljsku Motivaciju. Rezultati: Rezultati su pokazali da su učesnici u našem istraživanju motivisani za roditelj-

\section{REFERENCES}

1. Leurs R, Church MK, Taglialatela M. H1-antihistamines: inverse agonism, anti inflammatory actions and cardiac effects. Clin Exp Allergy. 2002; 32(4): 489-98.

2. Lovretić V, Mihaljević-Peleš A. Je li poremećaj kognitivnih funkcija put u depresiju? Zagreb: Soc. Psihijat. 2013; 41(2): 109-17.

3. American Psychiatric Association. Diagnostic and statistical manual of mental disorders: DSM-IV. Washington, DC: American Psychiatric Association. 2000.

4. Bech P, Rasmussen NA, Olsen LR, Noerholm V, Abildgaard W . The sensitivity and specificity of the Major Depression Inventory, using the Present State Examination as the index of diagnostic validity. J Affect Disord. 2001; 66 (2-3): 159-64.

5. Olsen LR, Jensen DV, Noerholm V, Martiny K, Bech P. The internal and external validity of the Major Depression Inventory in measuring severity of depressive states. Psychol Med. 2003: 33 (2): 351-6. stvo najčešće instrumentalnom motivacijom, dok su altruistička i fatalistička motivacija jednako prisutne, a narcistička je na najnižem nivou. Instrumentalni, fatalistički i altruistički motivi za roditeljstvo su značajno niži u grupi ispitanika sa depresijom. Nije bilo razlike među grupama kada se radi o narcističkoj motivaciji. Zaključak: Ova otkrića mogu biti viđena u svetlu opšteg stanja i karakteristika ljudi koji pate od depresije. Kod njih su konkretno svi aspekti motivacije smanjeni tako da nije iznenađujuće što je to slučaj i sa motivima za roditeljstvo.

Ključne reči: depresija, altruistička, fatalistička, narcistička, instrumentalna motivacija.

6. Di Parrón T, Hernández AF, Villanueva E. Increased risk of suicide with exposure to pesticides in an intensive agricultural area. A 12-year retrospective study. Forensic Sci Int. 1996; 79(1): 53-63.

7. Wilson RS, Hoganson GM, Rajan KB, Barnes LL, Mendes de Leon CF, Evans DA. Temporal course of depressive symptoms during the development of Alzheimer disease. Neurology. 2010; 75(1): 21-6.

8. Ivanušić J, Degmečić D. Klinička slika, dijagnoza i diferencijalna dijagnoza depresivnih poremećaja. MEDIX. 2013; 19(106): 139-43.

9. Urlić I. Depresija u 21. stoljeću - u povodu obilježavanja Europskog dana borbe protiv depresije. MEDIX. 2013; 19(106): 174.

10. Vidrih B, Karlović D, Bošnjak-Pašić M, Uremović M, Kovak-Mufić A, Matošić A. Pregled psihoneuroimunoloških spoznaja o etiologiji depresivnih poremećaja. Acta Clin Croat. 2012; 51(3): 403-9.

11. Zavoreo I, Bašić-Kes V, Bosnar-Puretić M, Demarin V.c Depresija nakon moždanog udara. Acta Clin Croat. 2009; 48(3): 333 . 
12. Čudina-Obradović M, Obradović J. Rađanje djece u obitelji. Psihologija braka i obitelji. Zagreb, Golden marketing-Tehnička knjiga, 2006.

13. Adler MA. Social change and declines in marriage and fertility in Eastern Germany. Journal of Marriage and the Family. 1997; 59(1): 37-49.

14. Friedman D, Hechter M, Kanazawa SA. Theory of the Value of Children. Demography. 1994; 31(3): 375-401.

15. Kohler H, Rodgers JL, Christensen K. Is fertility behavior in our genes? Findings from a Danish Twin Study. Population and Development Review. 1999; 25(2): 253-88.

16. Schoen R, Kim YJ, Nathanson CA, Fields J, Astone NM. Why do Americans want children? Population and Development Review. 1997; 23(2): 333-58.

\section{Correspondence to/Autor za korespondenciju}

Almedina Š. Numanović

Vehba Kolašinca 14,

36300 Novi Pazar, Serbia

email: almedinaasotic@yahoo.com

tel: 069626232
17. Miller WB, Pasta DJ. The Psychology of Child Timing: A Measurement Instrument and a Model. Journal of Applied Social Psychology. 1994; 24(3): 218-50.

18. Teachman JD, Schollaert PT. Gender of children and birth timing. Demography. 1989; 26(3): 411-23.

19. Rabin AI. Motivation for Parenthood. Journal of Projective Techniques and Personality Assessment. 1965; 29(4): 405-13.

20. Tucak-Junaković I, Ahmeti I. Motivacija za roditeljstvo i briga za mlađe naraštaje u mlađih i sredovječnih roditelja. Društvena istraživanja. 2012; 21(2): 363-82.

21. Vizler J. Povezanost percepcije roditeljskog ponašanja i sramežljivosti i asertivnosti školske djece. Diplomski rad. Zagreb: Odsjek za psihologiju Filozofskog fakulteta u Zagrebu, 2004.

22. Fromm, E. Man for himself: an inquiry into the psychology of ethics. Holt, Rhinehart and Winston, New York, 1947. 